\title{
Corporate social responsibility as a part of benchmarking analysis: case study of the Slovenian and Croatian hotel industry
}

\author{
T. Planinc ${ }^{1}$, G. Ivankovič ${ }^{1}$, M. Jerman ${ }^{2}$ \& M. U. Maravić ${ }^{1}$ \\ ${ }^{1}$ Faculty of Tourism Studies, University of Primorska, Slovenia \\ ${ }^{2}$ Faculty of Management, University of Primorska, Slovenia
}

\begin{abstract}
In Slovenia and Croatia, tourism (and within tourism especially the hotel industry) is a very important sector of the national economy. If we aim to get the complete picture of performance of the hospitality industry, we must conduct a performance analysis, considering both financial and non-financial indicators. Despite the recognized economic importance, the hotel sector on both sides of the border is facing problems related to differences in the methods of internal monitoring and measuring financial performance. The Slovene hotel sector still has not implemented the Uniform System of Accounts for the Lodging Industry (USALI). Implementation of the USALI is especially important when comparing hotel performance at a local, regional, national or world level, since the uniform accounting system allows the determination of industry norms on a regional, national and international level. Furthermore, the measurement of non-financial indicators such as corporate social responsibility is lacking. In order to enable the Slovene and Croatian hotels to implement a uniform system of benchmarking analysis and thus strive for increasing the level of hotel industry economic development, a joint methodology for monitoring financial and non-financial performance of Slovene and Croatian hotels is in the phase of development. This methodology is being developed as part of an EU project founded by the Operational Programme Slovenia-Croatia 2007-2013. The purpose of this paper is to present the Slovenian and Croatian benchmarking methodology of hotel performance analysis with the emphasis on the development of indicators of corporate social responsibility.
\end{abstract}

Keywords: corporate social responsibility, hotel industry, Slovenia, Croatia, benchmarking analysis. 


\section{Introduction}

The tourism industry (as a service industry) is among the world's largest industries and because of its labour intensity it is also an important generator of employment, especially in rural areas [1]. One of the main reasons why governments support and encourage the development of tourism around the world, is that it has a positive impact on economic growth and development. This means that tourism has a positive effect on GDP which is most commonly used as a benchmark for analysing the economic development of a country. Tourism can also help solve the unemployment problem and replace activities that are losing their competitive advantage (particularly in agriculture). In addition, tourism has a multiplier effect on many economic activities, such as transport, trade, construction, agriculture, etc. [2, 3]. In 2009 the hotel industry worldwide faced a decline in demand and in almost all destinations the occupancy rate in hotels decreased. This decrease reflected in a fall of revenue per available room, which in Europe fell by more than 32 percent. In time of global economic crisis many countries have recognized that tourism can contribute significantly to reducing unemployment and therefore have adopted a series of measures in the field of marketing and promotion of their country as a tourist destination [4]. According to World travel and tourism council, in 2013, travel and tourism contributed 2.2 trillion US\$ to world gross domestic product (9.5 percent of total GDP) and created 101 million jobs [5]. In Slovenia and Croatia, tourism (and within tourism especially the hotel sector) is a very important sector of national economy. In 2013 travel and tourism total contribution to GDP in both countries was 12.8 and 27.7 percent, respectively [6]. Net occupancy rate of bed-places in hotels and similar accommodation in 2012 in Slovenia and Croatia was 42.6 percent and 53.1 percent, respectively [7].

The structure of this paper is as follows. First, we highlight the importance of tourism and hospitality industry. Then we present the importance of benchmarking analysis and corporate social responsibility. Next we present the development of joint methodology of performance analysis with the emphasis on the development of indicators of corporate social responsibility. Conclusions, limitations and proposals for future development of benchmarking analysis conclude this paper.

\subsection{The importance of benchmarking}

If we aim to get the complete picture of performance of the hospitality sector, we must conduct a performance analysis considering both, financial and non-financial indicators, as Meyer [8] said "no single measure provides a complete picture of the performance of the organization". Benchmarking in hotel sector is not unknown to researchers [9-11]. Some companies perform benchmarking analysis for the worldwide hotel industry, such as Horwath HTL, PKF Hospitality Research, Ernst and Young and Smith Travel Research. When performing a benchmarking analysis it is important to use a uniform accounting system. Such system allows determining industry norms on all levels [12]. Researchers recognized the importance of non-financial indicators and so the Balanced Scorecard was developed [13]. 
Hotel sector understood the importance of benchmarking that is why it implemented the Uniform System of Accounts for the Lodging Industry (USALI). In January 2015 , the $11^{\text {th }}$ edition will be published. Implementation of the USALI is especially important when comparing hotel performance, since uniform accounting system allows determining industry norms on a regional, national and international level. Unfortunately, Slovene hotel sector still hasn't implemented the Uniform System of Accounts for the Lodging Industry (USALI). In 2009 an analysis of financial performance of Slovene and Croatian hotel sector was conducted. This comparative analysis focused on publicly available financial data. The results showed that despite increasing revenues, companies are still unsuccessful due to too high operating expenses [14].

\subsection{The importance of corporate social responsibility (CSR)}

The main idea behind CSR is that companies have responsibility to society, which is greater than just creating jobs and making profit [15]. Corporate social responsibility is in the spotlight of researchers since the 1950s and there are plenty of definitions of CSR. Carroll [16] wrote a literature review on CSR definitions and in another research, Dahlsrud [17] counted almost 40 definitions and these definitions often refer to five dimensions (voluntariness, stakeholder, social, economic, environmental). Researchers identified several dimensions of CSR which occur in different industries, such as environment, human resources, local community, employees, products, etc. [18-21]. The European Union has also recognized the importance of corporate social responsibility and in 2001 European Commission has issued a green paper on CSR with the aim of launching a wide debate on this subject at national and international level. CSR can have direct and indirect economic impact. Direct impacts arise from a better working environment, whilst indirect impact arise from the growing attention of consumers. In addition the European Commission recognizes internal (human resource management, health and safety at work, adaptation to change and management of environmental impacts and natural resources) and external (local communities, business partners, suppliers and consumers, human rights and global environmental concerns) dimension of CSR [22]. In 2011 the European Commission published new definition of CSR as "the responsibility of enterprises for their impacts on society" [23].

Interesting aspect is also how companies report on their CSR activities. According to Golob and Bartlett [24], CSR reporting is very important tool for communication with stakeholders regarding to CSR activities. In 2013, the KPMG International conducted a survey of corporate responsibility reporting. They assessed CR reporting among the 100 largest companies in 41 countries; the survey involved 4100 companies. 71 percent of companies undertook the practice of CSR reporting and over half companies include CSR reporting in their annual reports [25]. When it comes to reporting, we cannot evade the Global Reporting Initiative (GRI). GRI promotes the use of sustainability reporting and has developed s sustainability reporting framework that is widely used around the world. Last year GRI released the fourth generation of its Guidelines - G4. Guidelines propose three categories of reporting; economic, environmental and 
social category [26]. CSR reporting is on the rise as more and more stakeholders demand the information on company's CSR activities [27]. In her study, de Grosbois [27] came to conclusion that a large number of hotel companies recognize the importance of CSR, but only a small number of hotel companies disclose which activities they took in order to achieve CSR goals. Countries worldwide have different regulations regarding CSR disclosure. Reporting on CSR can be either mandatory or voluntary. In Slovenia the Companies Act in its article 70 states that if necessary, a company should include information regarding to environmental protection and workers into their annual report [28]. In Denmark, for instance, since 2009 companies must disclose their CSR activities and use of environmental resources [29]. Companies use different channels to report on their CSR activities such as reports, the Internet, and advertising campaigns [30, 31].

Tourism and hotel sector can also have negative economic, social and environmental impacts and when implementing corporate social responsibility, hotel companies can somewhat alleviate these negative impacts. Negative impacts reflect in air and noise pollution, occupation of space and infrastructure, large consumption of natural resources, etc. [32]. Despite this fact, hotel sector didn't get so much attention from researchers when it comes to CSR. This has changed over the past decade. There are numerous studies investigating implementation of CSR in specific hotel companies. Most common dimensions of CSR in hotel sector are local community, environment, human resources, and marketplace policies [27, 33-36]. Another important view is the relationship between companies' CSR activities and financial performance. The theoretical review of previous research showed that there are three groups of researchers. The first group has found a negative relationship between CSR activities and financial performance; the second group has found a positive relationship and the third group didn't find particular relationship [37, 38]. Researches that investigate the linkage between CSR activities and financial performance of hotel companies are scarce and in most cases they determined positive relationship [37-40].

\section{Methodology}

In order to enable the Slovene and Croatian hotels to implement a uniform system of benchmarking analysis and thus strive for increasing the level of hotel sector economic development, joint methodology for monitoring financial and non-financial performance of Slovene and Croatian hotels is in the phase of development. This project is founded by Operational programme SloveniaCroatia 2007-2013. The full project title is Benchmarking of Croatian and Slovenian hotel sector: instrument to increase competitiveness and entrepreneurship development. The main specific cross-borders objective is to create dynamic cross-border area of cooperation between hotel enterprises with aim of enabling comparison of their business in order to increase the level of economic development of Croatian and Slovenian hotel sector and tourism entrepreneurship in general. 
The development of joint methodology will result in a benchmarking software. Benchmarking software is a tool that will allow analysis and comparison of the hotel performance by identical criteria in Slovenia and Croatia. Comparative performance analysis is based on a large number of financial and non-financial indicators. Indicators are entered into the software on a daily, monthly or annual basis. Financial indicators are revenues by departments (according to USALI), direct costs, and unallocated controllable and uncontrollable costs. Non-financial indicators are general information about the hotel facilities, number of arrivals and overnights stays, and market share of different target groups, share of regular hotel guests, structure of domestic and foreign guests, country of origin of foreign guests, methods of hotel reservation, guests' satisfaction, employee satisfaction and corporate social responsibility.

Based on the data entered, the software calculates occupancy rates, average daily rate, revenue per available room and total revenue per available room, share of revenue by department in all revenues, GOP by occupied room, share of GOP in revenues, share of unallocated costs in revenues, share of direct costs by departments in revenues, etc.

All the data is entered in the benchmarking software by a qualified person in a hotel company. After entering the data, the hotel company can choose at least three other hotels, who also use the benchmarking software. Then the hotel can compare its own value of a specified indicator to the lowest, highest and average value of chosen hotels. For benchmarking, the hotel must choose at least three other hotel from the database. Hotel can't choose other hotels by its name, but they select their benchmark based on its characteristics (number of rooms, type of a hotel, number of stars, etc.).

The first step in creating the non-financial part of joint methodology of performance analysis was to perform the literature review on the subject of CSR. Based on the literature review, we prepared indicators that would in our opinion measure the level of CSR of each hotel company. Next, we organised three workshops in Slovenia and three workshops in Croatia for hotel companies. At these workshops we presented the project and its objectives and our proposal of non-financial indicators. We discussed non-financial indicators with representatives of hotel companies, who gave us very useful feedback.

After finalizing the non-financial indicators, we prepared all necessary data for the information technician, who developed software tool for gathering and comparing non-financial data.

\section{Results and discussion}

The result of a literature review and workshops for representatives of hotel companies was a set of non-financial indicators that include market segmentation, guests' satisfaction, employee satisfaction and corporate social responsibility. The focus of this paper is on CSR, so we will present indicators for measuring the company's CSR activities. We had to consider some limitations that referred to the number of non-financial indicators. We could propose numerous indicators in order to fully embrace all dimensions of CSR, but we had a limitation to propose 
no more than eight indicators. Although CSR is important, in the case of developing the benchmarking software, it represents only one aspect of a company's performance. Therefore, CSR must not prevail regarding to other indicators.

A set of non-financial indicators regarding CSR and corresponding formulas are presented in Table 1 and Table 2. When considering which indicators include in the benchmarking software, we tried to take into consideration all the dimensions of CSR that were identified thru literature review. We only excluded the dimension of human resources. Namely, this dimension is covered in non-financial indicators that comprehend employee satisfaction.

Table 1: Indicators for measuring the company's CSR activities.

\begin{tabular}{|l|l|}
\hline \multicolumn{1}{|c|}{ Dimension } & \multicolumn{1}{c|}{ Indicator } \\
\hline Local community & Share of given donations in general operating profit \\
\hline \multirow{4}{*}{ Environment } & Water usage per occupied and available room \\
\cline { 2 - 2 } & Electricity usage per occupied and available room \\
\cline { 2 - 2 } & Oil usage per occupied and available room \\
\cline { 2 - 2 } & Gas usage per occupied and available room \\
\cline { 2 - 2 } & Share of investment into energy efficiency of buildings in GOP \\
\cline { 2 - 2 } & Share of costs of printed promotional material in GOP \\
\hline Marketplace policy & Turnover ratio of liabilities to suppliers \\
\hline
\end{tabular}

Table 2: Formulas for calculating the indicators for measuring the company's CSR activities.

\begin{tabular}{|c|c|}
\hline Indicator & Formula \\
\hline $\begin{array}{l}\text { Share of given donations in } \\
\text { general operating profit }\end{array}$ & $\frac{\text { value of given donations in EUR }}{\mathrm{GOP}} \times 100$ \\
\hline \multirow{2}{*}{$\begin{array}{l}\text { Water usage per occupied and } \\
\text { available room }\end{array}$} & used water in cubic meters \\
\hline & $\overline{\text { number of occ. and available rooms on an annual level }}$ \\
\hline \multirow{2}{*}{$\begin{array}{l}\text { Electricity usage per occupied } \\
\text { and available room }\end{array}$} & used electricity in $\mathrm{kWh}$ \\
\hline & $\overline{\text { number of occ. and available rooms on an annual level }}$ \\
\hline \multirow{2}{*}{$\begin{array}{l}\text { Oil usage per occupied and } \\
\text { available room }\end{array}$} & used oil in liters \\
\hline & $\overline{\text { number of occ. and available rooms on an annual level }}$ \\
\hline \multirow{2}{*}{$\begin{array}{l}\text { Gas usage per occupied and } \\
\text { available room }\end{array}$} & used gas in cubic meters \\
\hline & $\overline{\text { number of occ. and available rooms on an annual level }}$ \\
\hline \multirow{2}{*}{$\begin{array}{l}\text { Share of investment into } \\
\text { energy efficiency of buildings } \\
\text { in GOP }\end{array}$} & investment into energy efficiency of buildings \\
\hline & GOP \\
\hline \multirow{2}{*}{$\begin{array}{l}\text { Share of costs of printed } \\
\text { promotional material in GOP }\end{array}$} & share of costs of printed promotional material \\
\hline & $\begin{array}{c}\text { GOP } \\
\end{array}$ \\
\hline \multirow{2}{*}{$\begin{array}{l}\text { Turnover ratio of liabilities to } \\
\text { suppliers }\end{array}$} & costs of goods, material and services \\
\hline & average value of liabilities to suppliers in EUR $\times 100$ \\
\hline
\end{tabular}

Dimension of the local community is covered with the indicator "share of given donations in general operating profit (GOP)". 
Environmental dimension is covered with several indicators such as "water usage per occupied and available room", "electricity usage per occupied and available room", "oil usage per occupied and available room", "gas usage per occupied and available room", "share of investment into energy efficiency of buildings in GOP", and "share of costs of printed promotional material in GOP".

Dimension of marketplace policy is covered with the indicator "turnover ratio of liabilities to suppliers".

Data, necessary for the calculation of these indicators, are entered in the benchmarking software on an annual basis by a qualified person in a hotel company.

Besides entering the data in the software, a qualified person will also fulfil a questionnaire regarding to CSR activities of a hotel. This questionnaire will be also fulfilled once a year. The questionnaire is composed of 6 statements and a person must tick one appropriate response for each statement on a five point Likert-type ordinal scale, ranging from 1 (strongly agree) to 5 (strongly disagree). The statements are written below:

a) our hotel on time (within the contractual time limits) pays liabilities towards suppliers

b) our hotel is active in the separation of all types of waste

c) our hotel is active in recycling (re-use within the company, for example wastewater, paper)

d) our hotel is active in energy savings (electricity, heating/cooling)

e) our hotel regularly provides financial assistance in the activities and projects of the local community (sponsoring of local sports clubs, charitable contributions, etc.)

f) our hotel cooperates with the Slovenian producers

The aim of this questionnaire is to raise the company's efforts regarding the CSR activities. With this questionnaire we will also check the consistency of answers with the results of the data analysis from the benchmarking software.

At the moment, the project is in the phase of developing bilingual implementation manual on gathering, analysis and comparison of non-financial data and indicators.

Benchmarking software presents an innovative tool for comparison the financial and non-financial indicators of Slovenian and Croatian hotel companies. It represents an enhancement of measuring systems in hotel sector through cooperation with educational-research institutions. With the use of this software, hotels can get the information how do they perform in comparison to their competition, in which areas other hotels perform better and why. Therefore this software is also an important tool for raising the competitiveness of a hotel companies. So it is crucial that hotels realize benefits and opportunities of this benchmarking software, so it will be in their interest to permanently use the software.

With the development of this software we are also creating conditions for further cooperation and exchange of good practices between Slovenian and Croatian hotel sector. The opportunity of this software also lies in expansion to other countries. 


\section{References}

[1] WTO. Tourism services [Internet]. 1998 [cited 2012 May 2]. Available from: Http://www.wto.org/english/tratop_e/serv_e/w51.doc

[2] Ivanov S, Webster C. Measuring the impact of tourism on economic growth. Tour Econ. 2007; 13(3): 379-88.

[3] Proença S, Soukiazis E. Tourism as an economic growth factor: a case study for Southern European countries. Tour Econ. 2008; 14(4): 791-806.

[4] Smeral E. Impacts of the world recession and economic crisis on tourism: Forecasts and potential risks. J Travel Res. 2010; 49(1): 31-8.

[5] Economic Impact Research [Internet]. World travel \& tourism council. 2014 [cited 2014 Jun 3]. Available from: http://www.wttc.org/ research/economic-impact-research/

[6] Wttc. Economic data search tool [Internet]. 2014 [cited 2011 Jun 19]. Available from: http://www.wttc.org/eng/Tourism_Research/Economic Data Search Tool/

[7] Statistics main tables [Internet]. Eurostat. 2014 [cited 2014 Jun 3]. Available from: http://epp.eurostat.ec.europa.eu/portal/page/portal/tourism/ data/main tables

[8] Meyer MW. Rethinking Performance Measurement: Beyond the Balanced Scorecard. Cambridge: Cambridge University Press; 2003; 218.

[9] Pine R, Phillips P. Performance comparisons of hotels in China. Int J Hosp Manag. 2005 Mar; 24(1): 57-73.

[10] Hua N, Nusair K "Khal", Upneja A. Financial characteristics and outperformance: Evidence of a contemporary framework from the US lodging industry. Int J Contemp Hosp Manag. 2012 May 25; 24(4): 574-93.

[11] Gu Z. Hospitality Investment Return, Risk, and Performance Indexes: a Ten-Year Examination. J Hosp Tour Res. 1994 May 1; 17(3): 17-26.

[12] Harris PJ, Brander Brown J. Research and development in hospitality accounting and financial management. Int J Hosp Manag. 1998 Jun 1; 17(2): $161-82$.

[13] Kaplan RS, Norton DP. The balanced scorecard-measures that drive performance. Harv Bus Rev. 1992; 70(1): 71-9.

[14] Ivankovič G, Jerman M, Jankovič S. Primerjalna analiza finančne uspešnosti hotelskega sektorja med Slovenijo in Hrvaško. Acad Tur. 2009 Dec; 2(3/4): Str. 32-39.

[15] Carroll AB, Shabana KM. The business case for corporate social responsibility: a review of concepts, research and practice. Int J Manag Rev. 2010; 12(1): 85-105.

[16] Carroll AB. Corporate social responsibility evolution of a definitional construct. Bus Soc. 1999; 38(3): 268-95.

[17] Dahlsrud A. How corporate social responsibility is defined: an analysis of 37 definitions. Corp Soc Responsib Environ Manag. 2008; 15(1): 1-13.

[18] Ahmad NNN, Sulaiman M, Siswantoro D. Corporate social responsibility disclosure in Malaysia: An analysis of annual reports of KLSE listed companies. Int J Econ Manag Account. 2003; 11(1). 
[19] Ponnu CH, Okoth MO. Corporate social responsibility disclosure in Kenya: The Nairobi stock exchange. Afr J Bus Manag. 2009; 3(10): 601-8.

[20] Khasharmeh HA, Desoky AM. On-line Corporate Social Responsibility Disclosures: The Case of the Gulf Cooperation Council (GCC) Countries. Glob Rev Accountung Finance. 2013; 4(2): 39-64.

[21] Lipunga AM. Corporate Social Responsibility Reporting by Commercial Banks in Annual Reports: Evidence from Malawi. Int J Bus Soc Res. 2013; 3(9).

[22] Commission of the European communities. Green Paper: Promoting a European framework for Corporate Social Responsibility. Brussels: Commission of the European communities; 2001.

[23] European Commission. Corporate Social Responsibility (CSR) [Internet]. 2014 [cited 2014 May 4]. Available from:

http://ec.europa.eu/enterprise/policies/sustainable-business/corporatesocial-responsibility/index_en.htm

[24] Golob U, Bartlett JL. Communicating about corporate social responsibility: A comparative study of CSR reporting in Australia and Slovenia. Public Relat Rev. 2007; 33(1): 1-9.

[25] KPMG. The KPMG Survey of Corporate Responsibility Reporting 2013. Netherlands: KPMG; 2013.

[26] What is GRI? [Internet]. Global Reporting Initiative. 2014 [cited 2014 Jun 6]. Available from: https://www.globalreporting.org/information/aboutgri/what-is-GRI/Pages/default.aspx

[27] de Grosbois D. Corporate social responsibility reporting by the global hotel industry: Commitment, initiatives and performance. Int J Hosp Manag. 2012 Sep; 31(3): 896-905.

[28] Zakon o gospodarskih družbah [Internet]. Republika Slovenija, Državni zbor. 2014 [cited 2014 Jun 11]. Available from: http://www.dzrs.si/wps/portal/Home/deloDZ/zakonodaja/izbranZakonAkt?uid=78784D1 438E25002C1257C000039F556\&db=urad_prec_bes\&tip=doc

[29] Global CSR Disclosure Requirements [Internet]. Initiative for responsible investment. [Cited 2014 Jun 11]. Available from: http://hausercenter. org/iri/about/global-csr-disclosure-requirements

[30] Line M, Hawley H, Krut R. The development of global environmental and social reporting. Corp Environmental Strategy. 2002; 9(1): 69-78.

[31] Lober DJ, Campbell E, Jacques M. The 100 plus corporate environmental report study: a survey of an evolving environmental management tool. Bus Strategy Environ. 1997; 6: 57-73.

[32] Chung LH, Parker LD. Managing social and environmental action and accountability in the hospitality industry: A Singapore perspective. Account Forum. 2010 Mar; 34(1): 46-53.

[33] Holcomb JL, Upchurch RS, Okumus F. Corporate social responsibility: what are top hotel companies reporting? Int J Contemp Hosp Manag. 2007 Aug 28; 19(6): 461-75. 
[34] Font X, Walmsley A, Cogotti S, McCombes L, Häusler N. Corporate social responsibility: The disclosure-performance gap. Tour Manag. 2012 Dec; 33(6): 1544-53.

[35] Garay L, Font X. Doing good to do well? Corporate social responsibility reasons, practices and impacts in small and medium accommodation enterprises. Int J Hosp Manag. 2012 Jun; 31(2): 329-37.

[36] Tsai H, Tsang NKF, Cheng SKY. Hotel employees' perceptions on corporate social responsibility: The case of Hong Kong. Int J Hosp Manag. 2012 Dec; 31(4): 1143-54.

[37] Kang KH, Lee S, Huh C. Impacts of positive and negative corporate social responsibility activities on company performance in the hospitality industry. Int J Hosp Manag. 2010; 29(1): 72-82.

[38] Lee S, Park S-Y. Do socially responsible activities help hotels and casinos achieve their financial goals? Int J Hosp Manag. 2009; 28(1): 105-12.

[39] Rodríguez FJG, del Mar Armas Cruz Y. Relation between socialenvironmental responsibility and performance in hotel firms. Int J Hosp Manag. 2007; 26(4): 824-39.

[40] Nicolau JL. Corporate social responsibility: worth-creating activities. Ann Tour Res. 2008; 35(4): 990-1006. 